\title{
Local Economic Development and Urban Poverty Alleviation: The Case of Buffalo City Metropolitan Municipality
}

\author{
Roland Darlington Mbeba
}

University of Fort Hare rmbeba09@gmail.com

\section{Doi:10.5901/mjss.2014.v5n20p347}

\begin{abstract}
Local Economic Development has in recent years, gained wide spread acceptance, as a locality-based response to economic challenges. It is now firmly on the agenda of many national and local government and key international agencies. Reviewing extensive literature on $L E D$, the study sought to establish the impact of the LED strategy employed by Buffalo City Municipality, and assess the extent to which it has alleviated poverty. The study shows that the Buffalo City Metropolitan Municipality (BCMM) LED strategy has limited impact on poverty alleviation due to a myriad of factors. The paper is empirical and descriptive in design and relied on extensive literature review. The paper argues that there is significant room for a paradigm shift from predominantly pro-growth to pro-poor LED, and the necessity of adopting a comprehensive LED strategy that seeks to include of both pro-growth and pro-poor strategies. Both cannot operate without the other in the bid to promote development in Buffalo City, mainly through agriculture, tourism. SMMEs also have significant potential to bring about local economic development. Moreover, the promotion of Private-Public Partnerships plays an integral role in the socio-economic development of Buffalo City, and the participation of local people is even more fundamental, which will give them the opportunity to take charge of their own development. Therefore, the study advocates for a new LED agenda, which is pro-poor, all-inclusive, and moves away from 'piecemeal' project based LED activities, and adopts comprehensive economic programmes so that LED has significant impact on poverty alleviation.
\end{abstract}

Keywords: Local Economic Development, Poverty alleviation, Buffalo City Metropolitan Municipality

\section{Introduction}

LED is increasingly being recognized as an acute sphere for policy advancement in the broader developing world, not least in South Africa (Rogerson, 1995, 1997), but the world over especially in the developing world. Such measures have been adopted with the intention of enabling productive partnerships with significant stakeholders to create an accommodative environment for sustainable employment, small and medium enterprise establishment and development; promotion of human development, and decent work (Canzanelli,2001). This is meant to boost the strength of macroeconomic growth through increased local economic growth, to promote improved standards of living, advance the quality of life, alleviate poverty, promote viable employment creation, skills development and build capacity for future sustainable development. LED refers to the process of wealth creation, through the structured conscription of human, physical, financial, capital and natural resources in a locality (Nel \& Rogerson, 2005).

LED can be a community-empowering process within which the benefits for the community are far reaching. It advocates for the participation of side-lined groups in the developmental progressions to create their own prosperity so as to enforce a greater constructive impact on development in the area, promoting self-reliance and alleviating poverty (Wegelin \& Borgman, 1995; Vanderschueren et al., 1996; Wegelin, 1996; Rogerson, 1999).

South Africa has adopted developmental LED, and emphasized on Pro-Poor LED, which facilitates the major role played by government and particularly local government agencies in stimulating growth and development, accordingly establishing a fundamentally pro-poor policy focus, with the aim of poverty alleviation (Nel\&Goldman, 2006). For instance South Africa has legislated policies such as the 'Refocusing Development on the Poor' in 2002, which evolved into the policy guidelines for implementing Local Economic Development in South Africa. In 2005 it was drafted into white paper policy legislated by parliament. These have ensured that LED aligns with a variety of government programmes as well as provincial strategies and local IDPs, with the holistic goal of being, innovative, creative in job-creation, economic growth as well as embark on sustainable rural development and urban renewal path to bring the previously disadvantaged and the poor to the centre of development (www.khanya-aicdd.org; Nel\&Goldman, 2006).

Poverty alleviation has been elevated in the LED policy agenda, as the extent, depth of poverty has affected many 
especially in the developing world. In the bid to alleviate poverty, LED has been widely initiated and implemented in both urban and rural geographical spheres in the form of pro-poor and pro-growth LED (Wegelin \& Borgman, 1995; Vanderschueren et al., 1996; Wegelin, 1996; Rogerson, 1999). Globally, the scope of conventional interventions surrounding urban-based LED have been deliberated in a significant appraisal by Vidler (1999). The review focused on four interventions, which represents the major areas of 'neo-liberal' policy convergence concerning planning for LED in urban areas. The four leading foci of urban LED interventions include; the promotion of the competitiveness of localities, principally by luring of inward investment, through boosting of development growth by instigating property-led city developments, promoting 'job creation from the inside' by instigating business retention or assisting small enterprise development (SMME) measures, and, more importantly, stimulating a variety of community development initiatives, comprising of community enterprises or cooperatives (Vidler, 1999; Rogerson,2008). These align to the pro-growth or market-led LED interventions, which emphasizes on the goals of encouraging individual self-reliance, entrepreneurship, development of the market, competitiveness, reduction of unemployment and sustainable development (www.buy.ipidaho.org). On the other hand there is now grown dominance in LED planning encompassing pro-poor LED or marketcritical which accentuates bottom-up approach propelled to achieve the goals of instigating local self-reliance, empowerment, participation, local cooperation, and environmental sustainability (Scott \& Pawson, 1999). It is thus of paramount importance to promote a new paradigm shift towards a comprehensive LED strategies in both urban and rural areas, with balanced pro-poor and pro-growth local economic development. For LED to have a significant impact on poverty alleviation, it is vital that there is a move away from away from solely 'piecemeal' project-based LED activities.

There has been extensive research on poverty in South Africa. Findings of major national investigation report on poverty and inequality, has revealed that the majority of the poor people as measured in monetary terms (defined as households who expend less than R 352, 53 per adult equivalent (1 US\$ to R 6.10), are situated in rural regions of South Africa (May, 1998).Nonetheless, the direction towards urbanisation and the breakdown of discriminatory controls on access to South African cities, more and more people are relocating from the rural to the urban areas and Buffalo City Metropolitan is no exception, as its rising population can be attributed to urbanisation (Rogerson, 1999).

Recent research highlights that urban poverty is a major policy issue that has gathered interest in post-apartheid South Africa (May, 1998; Rogerson, 1998a). Buffalo City Metropolitan is no exception, in that Buffalo City Quality of Life Survey, reveals that more than a third of the city's labour force is unemployed. Social inequality in Buffalo City is striking. Of all the Africans living in Buffalo City Metropolitan, over $45.5 \%$ are classified as poor' and approximately $21 \%$ of African residents were classified as ultra-poor, whilst $0.2 \%$ and $0.1 \%$ of Whites respectively fall into the poor and ultra-poor categories (IDP, 2010/2011).

The high levels of poverty are clearly spelt-out in the 2001 Census, which depicts that approximately $70 \%$ of households point out that they have an income of less than R1500 per month, which is the household subsistence level, with $28 \%$ of all households indicating that they have zero income, clearly implicating that most of the poor can barely afford basic necessities (IDP review, 2010/2011). "This clearly poses significant challenges for development in the city, and also suggests that, while average household income is getting bigger, a large portion of the city's population continues to struggle on the margins of the economy, as their sources of income diminish because of lack of employment opportunities"(Bank, Kamman, Meyer, Makubalo, 2007:42).

In addressing the challenging phenomenon of urban poverty in South Africa will require the mainstreaming of policy interventions at all three tiers of local, provincial and national government (Wekwete, 1998; Rogerson, 1999). The essential goal of this study is to deliberate on measures of local level interventions for urban poverty alleviation in South Africa, more specifically in the Buffalo City Metropolitan municipality (Rogerson, 1999).

\subsection{Research Methodology}

The study employed qualitative research methodology guided by a secondary research design, reviewing extensive literature. Reviewing extensive literature, yielded detailed reported information, and this conviction of enquiry enabled a deeper understanding of the effectiveness of LED as a poverty alleviation strategy (Creswell, 2008). The study adopted a case study design, and secondary research data was used to establish the social reality of LED and urban poverty alleviation, by examining documents related to the Buffalo City Metropolitan Municipality. Buffalo City Metro was purposefully selected as a unit of analysis from a number of municipalities in the Amathole District.

Purposive sampling was used to select the case of BCM as it illustrated some features or process in which the study took keen interest; in this case it is in reference to Buffalo City Metro LED activities and processes of poverty alleviation. Purposive sampling was applicable for the study as it targets a particular group of people, and settings (Silverman, 2010). The paper used descriptive and interpretative analysis with in-depth study of the research 
phenomenon. The analysis was descriptive in nature. Interpretative analysis was used through "description of the characteristics, processes, transactions, and context that constitute the phenomena being studied, couched in language not alien to the phenomenon, as well as the researcher's role in constructing this description" (Terre Blanche et al, 2006:321).

\section{Findings}

Buffalo City Metropolitan identified programs mainly focusing on key performance areas of Agriculture, Tourism, Infrastructure development, Skills development, SMME and business retention and expansion .The aim was to assess the impact of LED in not only fostering economic development, but also the extent to which it alleviates poverty. The BCM has an outlined five-year LED strategy aimed at improving economic growth, employment creation and human capital empowerment. Thus clearly directing its efforts in pursuing LED, as it is prescribed by the passing of the Municipal Systems Act (RSA, 2000).

\subsection{Agriculture}

Agriculture is one of the key sectors in BCM. A study carried out by the University of Fort Has substantiated the notion that agriculture plays a vital role in Local Economic Development (Hindson, Hindson \& Preddie, 2003). One particular urban agriculture venture initiated was the development of community nurseries (as in Duncan Village) and facilitating open access to the major fresh produce markets for small vegetable growers and in urban markets in East London and King Williams Town. This urban agriculture project fulfils the criterion that obliges municipal authorities to establish partnerships that mobilises both local government and private sector resources for joint projects managed by community groups. Additionally partnerships with aim of identifying niches in the local market with the potential for yielding opportunities for low-income households or individuals, was also be established (Roodt, 2003). The BCM has engaged in a various agricultural activities in partnership with other various stakeholders. For instance it is engaged in a partnership with the East London Industrial Development Zone, which has embarked on an exercise to provide access to pieces of land that have agricultural potential for production in hydroponics, aqua-culture and other related agro processing activities, which could all favour both local and international markets. Subsequently it offered a gateway for agricultural produce that comes from surrounding farming, hence a competitive edge for greater economic development based on the principles of equity, accessibility and impact (Afesis Corplan, Jan-Feb, 2011). A significant number of previously disadvantaged people have immensely benefited from agricultural activities such as tunnel farming and hydroponics to three co-operatives in Mdantsane, with the aid of the Department of Land Affairs (South African Cities Network, 2009). Significant positions were created from the hydroponics project, and some farmers received agricultural training from the Department of Agriculture. However the lack of funds posed the stumbling block to channel this project to other areas (BCM IDP, 2010-2011).

Additionally, the Cefane nursery project, which is located on the outskirts of East London, grows indigenous seedlings and plants, and distributing them to both local and international markets. The project has agricultural and heritage potential to be expanded so as to spread and preserve indigenous plants in other areas of the province (Hindson, Hindson \& Preddie, 2003). Furthermore the Gwaba shearing shed project, in ward 37, which was identified through the BCM Integrated Agriculture and Rural Development Strategy, was initiated with the intention to improve on the rural farmers' production. It specialised in sheep and wool farming, and instead of farmers simply producing wool, the shearing shed provided a facility for proper wool sorting and packaging, thereby adding value to the farmers' product. The department of Agriculture is involved in the livestock improvement scheme focused on improving the sheep flock for better production (Businesshikite.com/25/08/2011). Furthermore, about 850 commercial farmers, of which $2 \%$ are emerging farmers, and informal traders (hawkers) which constitute 35\% of the traders, supply the market, with fresh produce, and the East London Fresh Produce Market provides a suitable platform for locals to sell produce. It benefits a wide range of stakeholders more especially the historically disadvantaged groups as well provide an opportunity for local SMME's and Cooperatives involved in the Agricultural sector to participate (BCM annual report, 2009-2010). The agriculture sector presents opportunities for direct poverty reduction through the support to small-scale agriculture, as well as opportunities for larger scale job creation through commercial production and the exploration of beneficiation opportunities. Hence other investments in various potential niches in essential oil production and other exotic plants and crops have been identified (BCM IDP, 2011-2016). 


\subsection{Tourism}

The tourism sector is one of the key areas with great potential for poverty alleviation and has been taken as a key portfolio to be appropriately monitored to foster its growth and development in the Buffalo City Metropolitan. BCMM has the potential to benefit from the worldwide annual tourism growth of $5 \%-6 \%$, with domestic tourism to benefit more. (BCMM) and has since commissioned a Special Purpose Vehicle (SPV) and the Tourism Master plan in Buffalo City to drive the marketing of the city as a tourism destination, in partnership between the private and public sector (BCM IDP 2010-2011). This offers the platform for local stakeholders to significantly contribute in the planning process for key local development initiatives and in the execution as well as successful implementation of the initiatives with the aim for sustainable local economic development and alleviation of poverty. The SPV and the tourism master plan seeks to spearhead skills development and entrepreneurship in the tourism sector, as Buffalo City recognizes the responsibility of ensuring that the previously disadvantaged individuals are also benefiting from the sector (BCM IDP, 2009-2010). The Department of Economic Development and Environmental Affairs (DEDEA) has initiated and supported the Marketing of Tourism emerging entrepreneurs as part of the National Tourism Growth Strategy, and providing marketing platforms for the promotion of local products, in major events like the Tourism INDABA and the Kayalam Trade Show. The Heritage Route Development was also initiated through the partnership between municipality and National Heritage Council. The project has been heftily funded by the Department of Economic Development and Environmental Affairs to the tune of R2, 5 million (BCM IDP 2010-2011).

Additionally the BCM Buffalo City has initiated the Summer Season Programme, which is a marketing drive to promote Buffalo City as a tourist destination and attract visitors to the city, especially during the festive period, and has been funded to the tune of R1.3 million, thus creating gainful employment. SMME's have also been supported with the establishment of tourism centres in Mdantsane and Dimbaza, made possible through the corporation with the Industrial Development Corporation (IDC) to invigorate the Central Business District (CBD) and Quigney areas in East London (Hindson, Hindson \&Preddie, 2003). The Municipality annually provides strategic support to SMMEs to partake in trade shows and in the production of their marketing materials; at district municipality level, in 2009/2010 a week-long workshop on tourism was presented to teachers. Key portions of land have been identified, and the projects identified as being potentially prime investment opportunities that could drive tourism development and associated employment creation and tourism-led economic growth in Buffalo City. Significant projects include the Mdanstane community lodge Mdantsane Heritage Festival, A Community Game Farm in Macleantown, which significantly empowered the previously disadvantaged. (BCM IDP 2010-2011).

\subsection{Small, Medium and Micro Enterprises}

Small, Medium and Micro-Enterprise sector has had a significant impact on business development in Buffalo City Metropolitan Municipality. About 50000 small and micro-enterprises existing in the Buffalo City (BC) area and a further 80000 to 100000 people part-time or full-time involved in informal self-employment activities, the SMME sector plays a very important role in the economic dynamics of the city and in efforts to create jobs, add value and address issues of inequality and Black Economic Empowerment BEE (BCM LEDS 2008). The most significant challenge faced by SMMEs in BCM is the lack of access to finance and markets for SMME's as they struggle to access funds, resulting in bottlenecks for growth and development. BCM has three SMME Support Centres (Mdantsane One Stop Shop, Business Place eQonce and the Duncan Village Business Hives) as well as small business centres in Pakamisa and Dimbaza, which provide SMME support programmes, aimed at growing and developing small businesses. The centres provide, amongst others, business registration, business plan preparation, tender advice and training, emerging contractor development programme, market linkages, enterprise development, and information seminars. Some local SMME's have taken the initiative to provide training to their employees, with skills development in computer literacy, facilitation, customer service, information technology amongst others (Sinxoto, 2007). BCM has equipped and trained people through the SMME's support program with required skills to ensure marketability, and provide opportunities for (Highly Disadvantaged Individuals) HDl's to gain professional career based training, and assist with business plans, close corporation registrations, and close to 400 hawkers benefited from the capacity building initiative (theskillsportal, 2010). BCM has also established a Small-Business-Support Forum, BCM SME Information and Advice Desk (as part of the Customer Care Centre) played a role in providing a systematic monitoring of SMME progress.

The Business Unlimited Expo, Cooperative Support Fund, have been initiated to provide financial support to the formal and informal sector. Mentorship programs have also been implemented to offer capacity building and improve their competitiveness. Hence the establishment of the Informal Sector Development Programme, Emerging Contractor 
Development Programme, tender advice, SMME seminars. Furthermore, job-creating projects such as the Infrastructure development and Duncan Village Business Support Centre have been promoted (BCM IDP, 2010-2011). The municipality has also set out to implement a local business-diversification and expansion plan for Mdantsane, as it has realized the need to diversify, expand small-business-focused training as the need for critical skills, and balance the skills demand and supply. This was also meant to reduce high entrance barriers in terms of skills and capital inadequacy (BCDS, 2007).

Co-operatives have also played a significant role, as they have engaged in small scale business ventures. For instance Co-operative Development Fund has been initiated to provide financial support to primary co-operatives based in the city, as access to finance has been identified as one of the key challenges facing primary co-ops in BCM. They were supplemented with equipment and operational accessories supplies from the LED department as the municipality has recognised the potential of these co-ops and their contribution towards improving socio-economic well-being and broad-based economic empowerment (Buffalo city, 2011).

\subsection{Business retention and expansion}

The BCM has encountered enormous challenges, one being the relocation of businesses from Buffalo City to external destinations. This resulted in increased unemployment and loss of income. It is reported that during the period of 2006 to 2010, there were a number of firms that may have closed down and these are illustrated by sector as follows: 4 in the Manufacturing Sector, 2 in the Construction Sector, 2 in the Retail Sector, 1 in the Finance and Business Services Sector. Closure of 6 firms could result in +-1000 jobs loss, as well as diminished municipal rates and service income (Wolpe Development Strategies Buffalo City Business Survey, 2006). The failure to lure and retain businesses in BCM have been attributed to lack of skills and education, availability of finances, lack of business opportunities, service delivery, unemployment hence the lack of disposable income for the population to spend, crime and safety issues are of concern, as well as the lack of business opportunities. Hence concerted measures need to be implemented to attract and retain businesses.

\subsection{Skills Development}

Skills development forms a fundamental pillar for successful LED and poverty alleviation in Buffalo City Metropolitan. The city has a well-established further and higher education base, with large staff compliments, and has a working relationship that exists between selected institutions and a wide range of local corporations. Partnerships between the Municipality and learning institutions have a direct impact on business productivity, growth, and investment competitiveness (BCM LEDS, 2008). Buffalo City FET has developed training partnerships with VW and Damlier Chrysler and SAAB. In addition, through the Tooling Initiative SA programme they train students from various companies, Business Chamber forums and Council Reference Groups. The Human Resources Development Sector has limited Research and Development capacity and its contribution to these aspects of local development is limited, owing to poverty and lack of funds, thus compromising economic growth (BCM LEDS, 2008).

Through it Youth Development Strategy with the objective of building capacity, BCM has a comprehensive youth economic and skills development. It has spearheaded project management, budgeting, business plans and entrepreneurial skills with the assistance and corporation of all significant stakeholders, led by the BCM's LED and Tourism Department (Umhlaba Development Services, 2005). The Department of Labour, through the Labour Market Skills Development Program targets to support LED through plugging gaps in the local economy, SMME development, and by attracting investment in BCM and other adjacent areas, to curtail unemployment and economic degeneration(Roodt, 2003).

The BCM Expanded Public Works learnership Programme has also significantly contributed towards equipping the locals through a training programme. The EPWP instigated the training of contractors and 20 Supervisors. The outcome of the program was to formalise the informal sector by providing a platform for Small Medium Micro-Enterprises, government networking and sharing of information services to flourish. About Sixty SMME's were taken through the Tender Advice and Training Course, which was meant to promote entrepreneurship (BCM Annual Report, 2009-2010).

\subsection{Infrastructure development}

Infrastructure development is of great importance as a catalyst to local development. Building on a solid infrastructure foundation ensures sustainability of municipal services and support economic activity. $\mathrm{BCM}$ is experiencing a massive demand for municipal infrastructure flowing from increased household formation, thus is facing real infrastructure 
provision challenges (BCDS, 2007). Municipal infrastructure investment is backlog driven and focused on infrastructure extension rather than retention. Infrastructure development has been recognized as one of the fundamental interventions needed to be explored to tackle unemployment and address challenges facing the informal sector. Interventions through effective public works and infrastructure development spending by government provides significant opportunities of promoting and facilitating economic development and growth.

BCM's current infrastructure assets suffered from inadequate infrastructural maintenance- e.g. deferred maintenance of roads estimated at R350 million. A large housing backlog exists of $+-75,000$ units, additional demand for housing is expected in the future (BCDS, 2007). Moreover, according to BCDS (2007), existing bulk water, and sanitation infrastructure requires significant upgrading. For instance, with Mdantsane the focus area, the condition of the reticulation infrastructure, particularly in the urban core, is characterised by frequent pipe breaks and high level of unaccounted for water. On the other hand, the ability of the City to accommodate significant Growth (domestic and/or industrial) in the short-term, is limited and focused to certain areas close to existing services (BCM LEDS, 2008). The state of bulk sanitation infrastructure raises specific concern with various environmental threats and will need to be attended to so as to avoid a break out of an epidemic (BCDS, 2007).

$\mathrm{BCM}$ also has an extensive telecommunication infrastructure and telecommunication network license, which potentially could be made available to the public and/or special priority groups. Such initiatives enhance BCM's investment attractiveness in EL and IDZ and enhance growth in key manufacturing and service-based sectors such as tourism, which increasingly rely on e-commerce platforms.

\section{Discussion}

\subsection{Agriculture}

Buffalo City Metropolitan a predominantly urban locality fortunate to possess large tracks of land and forests for agricultural purposes. Agricultural land owned by both previously disadvantaged and advantaged members of the South African community, although chiefly owned by white minority, who are deeply engaged in commercial farming. However the majority of the previously disadvantaged seem not to gain much in commercial agriculture, which is dominated by the white minority. Nevertheless urban agriculture has played a potentially vital role in areas such as Mdantsane, Duncan village, Cefane East London where urban agriculture projects were initiated. Fresh produce nurseries and the small vegetable growers were given access to the Fresh Produce Market in East London. The Gwaba Sheering Project contributed into improving the farmers sheering production, producing quality wool to with stand competition, creating employment opportunities, and income generation, and alleviating poverty.

Private-Public partnerships the partnership between IDZ and Buffalo City Metropolitan has played a crucial role in establishing niche agricultural production, and other related agro-processing activities. Local farmers and some cooperatives with the support of the Department of Land Affairs have been allocated land and tunnels for hydroponic farming, and employment has been created. Though faced with financial challenges the hydroponic project significantly contributed to the development of Buffalo City, enhancing the capabilities and choices of the local community. Improving human capabilities widens the choices the people in the localities have and it is strategic in alleviating poverty (World Bank,2000; 2003).Hence enhancing people capabilities is the starting point or poverty alleviation. The agriculture sector presents opportunities for direct impact in efforts exerted in poverty alleviation in terms of support to small-scale agriculture, urban agriculture as well as opportunities for larger scale job creation through commercial production and the exploration of beneficiation opportunities.

\subsection{Infrastructure}

On the other hand, Infrastructure development has had stunted development which has negatively impacted on the basic operations of LED initiatives as there is serious infrastructure backlog (information, communication technology infrastructure and information systems applications) thus affecting basic service delivery and general provision of basic infrastructure necessary for the operation of enterprises. There has been progress in terms of providing infrastructure and services, with the local authorities directing efforts towards expansion programs and economic enhancement initiatives, which will have a significant impact in upgrading infrastructure and improving household access to basic services. There have been programs that have been implemented such as the Maintenance, Refurbishment and Upgrading Program focusing primarily at restoring efficient economic operation and capacity of existing bulk and reticulation infrastructure, and the expansion program largely focusing on the IDP housing program. 
The lack of direct funds remains a challenge towards specific infrastructure development activities, which are meant to directly affect the local population. Consequently the LED strategy has had limited ability to positively influence the standards of living. Therefore there is greater need to call for more comprehensive direct investment in infrastructure development with concerted efforts directed towards preparing logistics and a supportive business environment for domestic investment. This is so as it is a critical precondition for attracting "new" economic activities that are currently the basis for future economic growth, and also impact positively on Buffalo City's trade competitiveness in both exportlimport costs, as well as investment competitiveness to compete globally. One strategic action of enhancing the significance of infrastructure development is in the establishment and implementation of labour intensive construction projects, rather than machinery intensive construction work. Post-independence the South African government has since adopted a radical infrastructure development (Rogerson, 2004).

Failure to address infrastructure investment at the local level will result in failure of the city. Providing for effective and efficient infrastructure and leveraging off the current infrastructure foundation is crucial for the city to gear up for the future and build on the geo-physical connectivity of the city (BCDS, 2007). If people are to function effectively and efficiently at household and at employment/ business level, it is vital that they are supported with sufficient services, which include water, sanitation, electricity, roads, and telecommunications. Failure to provide the essentials will affect the efficient implementation of LED, hence it would remain a daunting if not an insurmountable task.

\subsection{Skills development}

There is a great deal of expansive room for human skills development in Buffalo City Metropolitan. There is evident potential that would significantly improve the Human Resource capacity of the city and its overall contribution to economic development. This can be achieved by enhancing interaction between the educational institutions: between them and city, business, industrial sectors and SETAs. It can also be done by encouraging sectoral fora to focus on skills development, research in key niche areas, improving the range of relevant career related skills training offered. It can also be initiated by improving student placement; identifying and responding to the training and development needs presented by new economic opportunities; and enhancing support for small businesses. The decisive implementation of skills development, inherently capacitates the local population, and therefore enhances the capabilities to be more involved and equipped to making significant contribution to socio-economic development, and in the process curb poverty. For instance, skills development through the tourism sector as dealt with in the BCM Tourism Master Plan with assistance from the Department of Economic Development and Environmental Affairs (DEDEA) is empirical evidence of capacitating the locals by marketing emerging entrepreneurs and disseminating skills to market their products. This has hence had substantial influence in plugging the gaps in the local economy, SMME development by attracting investment through offering a more capable workforce skilled in place marketing.

\subsection{Tourism}

The BCM tourism master plan shows great potential to spearhead local economic development, as it possesses great attractive scenery. The tourism master plan provides a platform that incorporates the involvement of the locals. Hence the involvement of communities and capacity building exercises are well-thought-out to be central to developmental approaches that seek out to extensively spread the economic benefits of tourism ventures (Rogerson, 2007). This thereby enforces Sen.'s capability approach which focuses on what individuals are effectively able to do and to be (Clark, 2006). In this case the locals are given the opportunity and freedom to participate in their own development, and in the process accumulate significant income and goods and thereby lead the kind of life they want, which is less povertystricken.

In as much as tourism has a room for growth, it will depend on a wide range of factors. These includes improvements in logistics infrastructure, tourism infrastructure (e.g. beach front), branding and marketing as well as additional resources are required to implement a number of priority initiatives, which have already been identified, as well consolidating the efforts of the Special Purpose Vehicles (SPV).

Tourism offers an opportunity of employment creation and significant income generation. Tourism has a potential to significantly contribute to local and national economic development initiatives, more so, can serve as a mechanism to promote pro-poor development initiatives and poverty alleviation in localities. Thus it is widely acknowledged as a key economic sector (Hill, Nel \&Trotter, 2006). The municipality is faced with the challenges of having to seek sustainable solutions to address the oversupply of tourism graduates that is not absorbed by the industry, which will provide the very much needed employment and empowerment opportunities. Tourism sector does not have that much of an impact in 
terms of employment creation in BCM as it is relatively has stunted growth. Hence the need for intervention measures that moderate equilibrium between the needs of the tourism sector and the provision of skills development program provided by teaching and learning institutions. Such efforts should also be done in collaboration with Department of Economic Development and Environmental Affairs(DEDEA) and the private sector, which will spearhead the funding for skills development programs, valuable expertise and experience in the Tourism Sector. Thus it is imperative to develop strong public-private partnership in order to provide sustainable economic development through tourism.

Skills development in tourism has a vital role to play towards skills and enterprise development, realizing what Kaplan (2004a) designates as South Africa's 'tourism-led development strategy' (Tecle \& Schroenn, 2006). Skills development complements tourism industry growth, as opportunities that are created in the formal tourism industry are filled by previously disadvantaged South Africans across all work spectrums. Moreover, the growth of this skills base should furnish a pool of potential new tourism entrepreneurs (Rogerson, 2008). This will ensure that people can be able to take advantage of opportunities created and benefit from development opportunities that will improve their standard of living, and alleviate poverty. Furthermore tourism awareness programs should be conducted at schools and community level, including utilizing experience and expertise of senior citizens to assist in the development of new ventures, as well as utilizing the expertise of retired sector practitioners. Hence eminently bring forth the creation of employment and income generation, improvement of the standard of living and hence poverty alleviation. Rogerson (2006) substantiates this notion by arguing that pro-poor tourism is a potential vehicle to drive local economic development.

\subsection{Business retention and expansion}

Retention and expansion of businesses is of vital importance in any locality to enable the locality to sustain its development and be able to compete in the dynamic development environment. It plays a vital role in addressing the challenges of economic development and sustainability. A conducive business environment with less red-tape ought to be promoted, and service delivery is provided efficiently and effectively, to satisfy local businesses. For LED to succeed, it is very imperative that local authorities have concerted efforts to retain businesses and provide room to expand. To retain and expand businesses it is imperative that there is adequate provision of basic services and infrastructure, as well as human capital development, advisory, capital and technical support. Hence the need for municipal administrative efficiency that will positively influence business establishment, business expansion, physical property development and investment. Furthermore vigorous marketing of Buffalo City is needed, to compete with other metropolitan cities like Port Elizabeth, and Johannesburg, which are in better marketing position as it attracts more investments, and attracts the economically active and literate people than Buffalo City.

\subsection{SMME development}

Business Development is a key economic development tool and BCM focused on the development of the second economy as its key intervention. Second economy (mostly comprised of SMME's) is known for its potential to create jobs, encourage entrepreneurship and improve competitiveness.

SMME development in Buffalo City has the great potential to instigate significant economic development, and poverty alleviation through the implementation of LED strategies, that deeply involve the poor population. More resources need to be deployed towards re-engineering LED in a way that promotes poverty alleviation through LED promoting SMME development at the same time involving the poor locals themselves. Lack of funding and credit is one of the major stumbling blocks faced by local SMME's in Buffalo City and other localities across the country. The state of SMME's in Buffalo City Metropolitan as well as in Johannesburg and Durban SMME's has indicated that, the lack of credit is the principal business development constraint (Chandra \& Rajaratnam, 2001; Skinner, 2005; Rogerson, 2008).

In collaboration with other stakeholders, the BCM has in place, a capacity building and corporative program, which has done well in supporting SMME's in finance and non-finance initiatives which have the potential to equip locals with skills. This is in line with Schumpeter's (1976) entrepreneurial skills where small businesses are equipped with skills to promote invention, innovation and diffusion of ideas (Schumpeter 1976; EDA 2005). This form of human capacitating will support small enterprises to grow in terms of income, market share and assets within the value chain. This will go a long way into ensuring that SMME's are capacitated to transform from being survivalist enterprises to growth enterprises. This can be noted in the program spearheaded by Buffalo City Metropolitan, where hawkers from the major nodes of Buffalo City such as King Williams Town, Mdantsane, and East London, received basic business training with emphasis on basic bookkeeping, stock control, health and hygiene, marketing and customer care. Rogerson (2008) authenticates this notion by asserting that enhanced access to financial management skills and business training are crucial strategic 
fundamentals in complementing the three pillars of promoting entrepreneurship; strengthening the enabling environment; and improved competitiveness and capacity at the enterprise level.

There is need for continuous access to relevant, up-to date, easily understandable information and advice for local entrepreneurs. Thus there is the need for strategic and systematic LED planning which takes into consideration of SMME's needs (Musakwa, 2008). Although yet to be established, the Small-Business-Support-Forum and the secretariat comprising all stakeholders, will have to play a vital role in SMME development once they are established and fully operational, of which they are at an advanced planning stage.

\section{Challenges of Implementing LED in Buffalo City Metropolitan Municipality}

$\mathrm{BCM}$ faces a wide range of challenges. One of which is that the new metropolitan has to take interest in strengthening the participation of the private sector and civil society, by providing an enabling environment conducive for development. There is also the challenge of centralisation and pooling of technical staff and resources to East London, which has greatly affected surrounding areas (Roodt, 2003). This brings to the fore the urgent need for training of municipal officers as identified by Nel (2001), who is of the view that there is greater need for large-scale capacity building, which will result in the pro-active group of LED officers, as they are trained and exposed to the concept of LED.

It has also been established that, the changing economic environment because of the recession; and that vacancies in the lower positions in the department; budget constraints; lack of economic intelligence; poor coordination between economic development institutions in the region; lack of coordination in the monitoring and evaluation processes and the lack of clear implementation of LED strategy, pose as the major hindrance towards total significant local economic development. It is important that a review of the economic development strategy and sector plans be reviewed. It is important to improve capacity of the Municipality's LED department by ensuring that there is enough personnel; development of an implementation plan for the Economic Development Strategy; ensure efficient institutional monitoring and evaluation tool; and institutional wide approach on Business Retention and Red Tape reduction process (BCM Annual Report, 2009-2010).

Another challenge that Buffalo City Metropolitan Municipality, also faced is that, it competes with other larger metropolitan municipalities, such as Port Elizabeth, Cape Town, Durban and Johannesburg. This is so in that it is still behind in terms of its ability to market itself as a potential tourist attraction. It however needs to improve in this regard, as it is to find it a lot harder to attract investors and an even more daunting task of retaining local businesses. This brings to the fore, the notion of the existence of a wide gap between cities and small centres, and the case of BCM, between and amongst the metropolitan cities themselves. The gap between and amongst cities and small centres needs to be considerably reduced, hence the need to establish agencies which will act as facilitators of economic development with dedicated capacity and strategic intent, which will equip local municipalities to continue with their constitutional and developmental mandate of addressing priority service provision and poverty alleviation (Bartlett, IDC, 2009).

\section{Conclusion}

The Buffalo City Local Economic Development initiative does to a certain extent contain integral elements focused on poverty alleviation, which unfortunately, has failed to have any influential effect directly on poverty, and thus has had limited effect. Similarly Dapira (2008), in her study came up with the observation and analysis that most of the LED initiatives are failing to bring about tangible social transformation and it would appear to be deriving only limited benefits. Nevertheless, poverty alleviation in Buffalo City is not a separate program, but an integral part of the Buffalo City Development Strategy (BCDS).

To a certain extent LED has had a significant impact in, urban agriculture, tourism and to a certain extent SMME support, and upgrading infrastructure and improving household access to basic services. LED initiatives should seek to promote innovative, appropriate LED approaches in the City, which goes beyond the city's traditional focus on large industry and sought to benefit and assist a far broader section of the city's society (Nel, 1999). There is also the need to identify key strategies with the main focus on enhancing the capacity of participating organizations, the undertaking of research to support the partnerships, key sectors and an examination of municipal functions to reorient its activities to support SMME's and informal traders (Kent,1996 as cited in Nel.EL.1999). It is also imperative for authorities to devise other strategies focusing on all forms of capital that are complementary to the LED strategy to curb poverty alleviation (Musakwa, 2008). This is so as poverty alleviation requires a concerted, multidimensional and coherent effort that should be guided by an over-arching strategic approach. There is need for policy shift in BCM towards poverty alleviation away from welfare provision and extension a more nuanced response to the needs of the poor (BCDS, 2007), with focus on 
public-participation and private-public partnerships. Thus a fair balance between pro-poor initiatives complemented by pro-growth economic development initiatives is essential. Private-Public partnerships are fundamental foundations for successful local economic development (LED) planning (Rogerson (2009).

It is the responsibility of local municipalities to provide the platform for invented public participation structures in the municipality. This will encourage civil society participation and support in community development. This can be initiated by establishing the Local Economic Development Agency (LEDA), which is to be tasked with playing a vital role in managing, directing, and coordinating economic development activities in the local spaces within Buffalo City Metropolitan area (Lawrence, 2013).Close corporation with the Amatole Regional Economic Development Agency (ASPIRE) will also enhance the capacity of the BCM to spearhead it's Local Economic Development Strategy, as it has emerged that that the good practices of Regional Agencies like ASPIRE can provide insight into enhancing operational, institutional and socio-political context for LED operations (McKibbin, Binn, Nel, 2012). There is also the need to have partnerships between government, private sector and civil society that will promote self-employment and capacity building in skills development and financial support. The Buffalo City LEDS needs to direct efforts towards accelerating job creation and economic growth as well as poverty reduction through building the informal sector, which comprises of the hawkers, and cooperatives, which are prominent in the poorest areas of Buffalo City Metropolitan. It is imperative to also instigate sustainable pro-poor LED policies and strategy implementation, with a combination of pro-growth LED that seeks to accomplish simultaneous goals of enhanced competitiveness on the one hand, and of poverty reduction on the other (Marriot, 2004; Nel, Hill \& Goodenough 2007). Conclusively it can be asserted that, BCM should therefore focus on formulating a comprehensive LED strategy that shows a balance between pro-growth and pro-poor LED, with an inclination towards pro-poor LED. The comprehensive strategy should be tailor made for BCM socio-economic environment. Thus the new LED agenda should not and cannot be done without consideration of the context it will be done in. Furthermore, this paper recommends that, BCM should thus initiate systematic LED monitoring and evaluation, to determine the impact of LED projects and programs, establishing what contribution LED has towards local governance and living conditions. LED monitoring and evaluation is both doable and affordable at project and at strategy level .Only a few systematic LED evaluations are out there in the public domain, and it would serve BCM better to expound the notion of LED monitoring and evaluation (DEZA, 2008).

It can thus be deduced that LED has the potential to considerably improve on the socio-economic environment of all localities. BCM has potential growth areas in the form of agriculture, tourism, SMME. Additionally, infrastructure development should not be ignored as it plays a crucial role as a catalyst for any development initiative to take place. $\mathrm{BCM}$ to a limited extent has assimilated pro-growth and pro-poor LED interventions, as it has already an established industrial zone and economic development initiatives. However it has made little progress in curbing poverty. Thus BCM needs to shift its LED strategy towards pursuing an all-inclusive LED practice subjugated by matters of developing systemic competitiveness with a sub-set of LED activities that are poverty alleviation-focused (Rogerson,2009). Buffalo City Metropolitan Municipality should follow up on the LED policies pursued by Mangaung, Cape Town and eThekwini municipalities who under-took a middle of the road approach, focusing their LED strategies that focus on both issues of poverty and growth and the fundamental linkages between the two dimensions (World Bank, 2005). In general, LED policy should clearly identify a path to be followed by all local authorities, and should be tailored for the different socioeconomic environment local governments find themselves.

\section{References}

Afesis Corplan (2011). Transformer. The Journal of Development and Governance issues. Vol 17, N0: 1 January-March 2011.

August (2009). 145 urban farmers go hydroponic route. Retrieved 20August 2011retrieved from: http://www.sacities.net/workwith /buffalocity/news

Bank.L, Kamman, E, Meyer, L, Makubalo, L. (2007). The Buffalo City Quality of Life Survey. Published by the Fort Hare Institute of Social and Economic Research (FHISER). Accessible online at: http://www.buffalocity.gov.za accessed online on (26 June 2011).

Bartlett, S. (2009). IDC supporting regional development: Agency development and support department business plan FY $2009 / 2010$. Internal document, IDC, Johannesburg.

Buffalo City Development Strategy (2007).Consolidation Report Version 4.1. Managing a city in transition. May 2007

Buffalo City Metropolitan (2010-2011). Draft Integrated Development Plan Review 2010 - 2011.

Buffalo City Metropolitan Annual Report 2009/2010

Buffalo City Metropolitan Municipality (2008). Buffalo City Local Economic Development Strategy (BC LEDS) (2008).

Buffalo City Metropolitan. Integrated Development Plan. 2009-2010

Buffalo City Metropolitan. Integrated Development plan. 2011-2016 
Businesshikite.com retrieved 25 August 2011.

Canzanelli, G. (2001). Overview and learned lessons on Local Economic Development, Human Development, and Decent Work. Geneva, ILO.

Chandra, V., Moorty, L., Rajaratnam, B. and Schaefer, K (2001). Constraints to Growth and Employment in South Africa: Report No. 1: Statistics from the Large Manufacturing Firm Survey, Discussion Paper No. 14, Informal Discussion Papers of the Aspects of the Economy of South Africa. The World Bank Southern Africa Department, Washington DC.

Clark.D.A. (2006) .The Capability Approach: Its Development, Critiques and Recent Advances. ESRC Global Poverty Research Group. GPRG-WPS-032.

Creswell, J.W. (1994). Research design: Qualitative and quantitative. London. Sage.

Dapira. C. (2008). Local Economic Development initiatives as an intervention measure for rural development: a case of Amathole District Municipality of the Eastern Cape, South Africa. (Masters Dissertation) University of Fort hare.

Direction fur Entwiclung und Zusammenarbeit (DEZA) (2008). How does Local Economic Development (LED) contribute to Poverty Reduction? The Relevance of Monitoring and Evaluation for LED Information note

Hill.T, .Nel.E. \& Trotter. D (2006). Small-scale, nature-based tourism as a pro-poor development intervention: Two examples in KwazuluNatal, South Africa. Discipline of Geography, School of Environmental Sciences, University of KwaZulu-Natal, Pietermaritzburg, South Africa.eprints.ru.ac.za.

Hindson, D, Hindson.V \&Preddie.M. (2003).Rapid Review of LED in the Eastern Cape. Department of the Eastern Cape Premiers Office. http://www.skillsportal.co.za/page/training/training_companies/retail wholesale training/143818. Eastern Cape hawkers receive business training .Retrieved 03 September 2011.

Kaplan, L. (2004a). Skills development in tourism: South Africa's tourism-led development strategy. GeoJournal, 60, 217-227

Kaplan, L. (2004b). Skills development for tourism in Alexandra Township, Johannesburg. Urban Forum, 15, 380-398.

Lawrence, F (2013). The Role of Local Economic Development Agencies in the South African Local Economic Development Landscape. Urban Forum (2013) 24:523-541

Marock, C. (2006). Reskilling the Tourism and Hospitality Sector: A Case Study of the Tourism Learnership Project, Learning Series No. 2, The Business Trust, Johannesburg.

Marriot, A. (2004). "What should be the balance of emphasis in South African cities between economic programmes focused on poverty reduction and those aimed at building globally competitive economic environments"? Unpublished paper, University of KwaZuluNatal, Durban.

May, J (1998). Poverty and Inequality in South Africa. Report Prepared for the Office of the Executive Deputy President and the InterMinisterial Committee for Poverty and Inequality. Durban: Praxis.

McKibbin, J., Binns, T., \&Nel, E. (2012). Uplifting small towns in post-apartheid South Africa: The experience of the Amatole Regional Economic Development Agency (Aspire). Local Economy, 27, 388-402.

Musakwa, W (2008). Local Economic Development as a Poverty alleviation tool: A case on the urban renewal KwaMashu (Masters Dissertation) University of Kwazulu Natal.

Nel, E (2001). Local economic development: A review and assessment of its current status in South Africa. Urban Studies, 38, 10031024.

Nel, E. \& Rogerson, C.M. (eds.).2005. Local Economic Development in the Developing World: The Experience of Southern Africa. Transaction Publishers: New Brunswick, N.J.

Nel, E. L. (1999) Regional and Local Economic Development in South Africa. The Experience of the Eastern Cape. 1999. Ashgate Publishing Limited.

Nel, E., Hill, T. R., \& Goodenough, C (2007). Multi-stakeholder driven local economic development: reflections on the experience of Richards Bay and the uMhlathuze municipality. Urban Forum, 18, 31-47.

Nel.E \& Goldman. I. (2006). Investigation of Pro-Poor Local Economic Development in South Africa. World Bank-Netherlands Partnership Program (BNPP). www.khanya-aicdd.org.

Rogerson .C.M (2008).Tracking SMME Development in South Africa: Issues of Finance, Training and the Regulatory Environment. Urban Forum (2008) 19:61-81.

Rogerson C. M (1998).Urban agriculture and urban poverty alleviation: South African debates, Agrekon, 37 (2), 171-188.

Rogerson C.M (1995). Local initiatives for urban economic development: the case of Johannesburg. Paper delivered at the International Geographical Union Commission Conference on 'Urban development and urban life'. Cape Town.

Rogerson, C. M (1997). International Migration, Immigrant Entrepreneurs and South Africa's Small Enterprise Economy, Migration Policy Series No. 3, The Southern Africa Migration Project, Cape Town.

Rogerson, C. M (2009). Local economic development and tourism planning in Africa: evidence from route tourism in South Africa. In P. Hottola (Ed.), Tourism strategies and local responses in Southern Africa (pp. 27-40). Wallingford: CABI.

Rogerson, C.M (1999). Local Economic Development and Urban Poverty Alleviation; the Experience of Post-Apartheid South Africa. Habitant, Vol 23, Number 4, 511-534. 1999.

Rogerson, C.M (2003). Towards Pro-Poor Local Economic Development: The Case for Sectoral Targeting in South Africa. Urban Forum, Vol. 14, No. 1, January-March 2003.

Rogerson, C.M (2007). Tourism Routes as Vehicles for Local Economic Development in South Africa: The Example of the Magaliesberg Meander. Urban Forum (2007) 18:49-68

Rogerson, C. M. (2008).Consolidating local economic development in South Africa. Urban Forum 19, 307-28. 
Rogerson.C. M (2004). Pro-Poor Local Economic Development in South Africa: The Application of Public Procurement. Urban Forum. Vol 15. No.2. April-June, 2004.

Rogerson. C.M (2006). Pro-poor Local Economic Development in South Africa: The Role of Pro-poor Tourism. Local Environment. Vol 11, No 1, 37-60, January 2006.

Roodt.M.J (2003). Local Economic Development and strategy for King William's Town. ECSECC.

RSA (2000).Municipal Systems Act, N0; 32 of 2000. Department of Local Government.

Scott, G \& Pawson, E (1999).Local development initiatives and unemployment in New Zealand. Tijdschrift voor Economische en Sociale Geografie, 90, 184-195.

Silverman. D (2010). Doing Qualitative Research. Third Edition. SAGE Publications Limited.

Sinxoto N.B (2007). The role of the Small, Medium and Micro sized enterprises (SMME's) in the socio-economic development of Buffalo City. Dissertation submitted in partial fulfilment of the requirements for the degree of Masters in Business Administration at the Nelson Mandela Metropolitan University Business School.

Skinner, C (2005).Constraints to Growth and Employment in Durban: Evidence from the Informal Economy, Research Report No. 65, School of Development Studies, University of KwaZulu-Natal, Durban.

Tecle, Y. H., \& Schroenn, J. L (2006). The contribution of HRD to tourism-led development in an African context. South African Journal of Economic and Management Sciences, 9(4), 444-457.

Umhlaba Development Services (2005) Buffalo City Youth Development Strategy 2005-2007.

Vanderschueren, F., Wegelin, E. \& Wekwete, K., (1996) Policy Programme Options for Urban Poverty Alleviation: A Framework for Action at the Municipal Level, Urban Management Programme Policy Paper No. 20, The World Bank, Washington DC.

Vidler, E (1999). City economic growth. Unpublished paper prepared for the British Department for International Development Urban Governance, Partnership and Poverty Conference, University of Birmingham, March.

Wegelin, E (1996). Options for municipal interventions in urban poverty alleviation. ; NCHS Habitat Debate 2 (2), 1$\} 5$.

Wegelin, E. \& Borgman, K (1995).Options for municipal interventions in urban poverty alleviation. Environment and Urbanization 7 (2), 131-152.

Wekwete, K. H (1998). Urban poverty reduction: towards mainstreaming and implementing urban poverty reduction plans in subSaharan Africa. Background paper prepared for the Africa Regional Workshop, Nairobi.

Wolpe Development Strategies (2007).Constraints to Investment in Cape Town.

World Bank (2000). Poverty Reduction Strategy Source Book: Core Techniques and Cross Cutting Issues. (Online). Available from: www.worldbank.org/ poverty/strategies/mailback.htm.

World Bank (2003). Local Economic Development: Quick Reference (Washington: Urban Development Division, World Bank).

World Bank-Netherlands Partnership Program (BNPP), 2005. "Investigation of Pro-Poor Local Economic Development in South Africa." 